International Journal on Biological Sciences 12 (1), January-June 2021, pp 33-40 https://doi.org/10.53390/ijbs.v12.i1.4

ISSN No.: 0976-4518

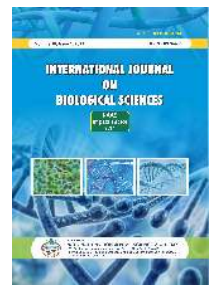

\title{
RAISING EXPERIMENTAL INFECTION OF PARAMPHISTOMOSIS IN SHEEP UNDER LABORATORY CONDITION
}

\author{
Syed Shabih Hassan \\ Department of Veterinary Parasitology, College of Veterinary Science \\ Guru Angad Dev Veterinary and Animal Sciences University, Ludhiana, Punjab
}

\section{Research Paper}

Received: 20.05.2021

Revised: 28.05.2021

Accepted: 05.06.2021

\begin{abstract}
Snails, the intermediate host are the transmitter of trematode infection in ruminants in the endemic areas of Punjab. Under DST-SERC-FAST-Track project(DST, GOI, New Delhi), the survey was conducted mainly in ponds, bank of the River Satluj and Beas its surrounding temporary water bodies, ditches, impoundments, near by tube well sand paddy fields in Ludhiana, Hoshiarpur Kapurthala and Amritsar district of Punjab. A total of 701 snails were collected, and seven species were identified as Indoplanorbis exustus, Gyraulus convexiusculus, Lymnaealuteola, L. auricularia, Bellamya (Vivipara) bengalensis, Corbicula striatella, and Thiara tuberculata. Out of the total collected snails, 365, 4, 165, 127, 16 and 24 were contributed by I. exustus, G. convexiusculus, Lymnaeasp., B. bengalensis, C. striatella and T. tuberculata respectively. Snails like I. exustus, G. convexiusculus and Lymnaeasp were found to be most prominent in ditches, impoundments, nearby tube wellsand paddy fields which play a very important role in the transmission of most pathogenic diseases like paramphistomosis and schistosomosis in ruminants respectively. The other snails were recorded to be common in bank of the River Satluj and its surrounding temporary water bodies. I. exustusan intermediate host of Paramphistomum spp. were kept in different batches individually in glass tubes as per Leiper's glass tube technique. Snails in bulk were also kept in beaker, surgical tray, earthenpots and petridishes with coloured poly then estrips to harvest metacercariae. Polythene strips of different colour, green, yellow and pink were used for the encystment of cercariae. These strips were stuck to the inner surface of the petridishes, beakers and surgical tray. Various encystment materials like water plants; lettuce and itsit (Trienthemagovinda) leaves were used. It was observed that maximum attraction of cercariae was towards itsit leaves followed by green and yellow polythene strips. Very few cercariae were also encysted onthe wall of the containers. 185 individuals of $I$. exustuswere found to be shedding cercariae with the prevalence rate of $55.89 \%$. The cercariae were identified ascerearia of Paramphistomum epiclitum. The collected metacercariae were used for raising the infection in sheep. A total of 12,040 metacercariae was collected from185 infected snails (I. exustus) and kept in polyvinyl tubes ( stored at $4^{\circ} \mathrm{C}$ ). These metacercariae were given orally to two sheep for raising paramphistome infection under experimental condition. The animals were subjected with 4000 metacercariae to each sheep. The grass with encysted metacercariae was also collected from thefields for feeding to sheep. Faecal samples examined microscopically and found positive for paramphistome eggs after 135 days post infection. The experiments confirm the transmission of paramphistome infection in sheep. This disease is highly pathogenic and there is a need to formulate control and preventive measures for the betterment of livestock industry.
\end{abstract}

Keywords: Experimental Infection, Paramphistomosis, Metacercariae, Sheep, Cercaria pigmentata.

\section{INTRODUCTION}

Parasites are profoundly influenced by physiological, genetical and immunological states of the host during infection. The host parasite relationship, in which the two interacting species are in a state of dynamic balance, both intending to propagate their own kind. Paramphistomosis

*Corresponding author: fish_ab@rediffmail.com 
is defined as the parasitosis found in domestic and wild ruminants caused by trematoda that in general belong to the family Paramphistomidae (Sanabria \& Romero,2008). Snails, the intermediate host are the transmitter of tremato deinfection in ruminants in the endemic areas of Punjab. Paramphistomosis of domestic ruminants constitute one of the major parasitic diseases which is of considerable significance in several areas of the country including Punjab state.The disease is caused by massive infection of the small intestine with immature paramphistomes and a major concern in low-lying areas as the snail population viz. Indoplanorbis, Lymnaea and Gyraulus spp (intermediate host in the life cycle of paramphistome) increases mainly during monsoon and post monsoon season, which is characterized by sporadic epizootics of acute gastroenteritis with high morbidity and mortality in young domestic animals. Immature parasites are pre dominant in dorsal and ventral sacs of rumen of buffaloes, sheep and goats (Varma et al, 1989). The death rate due to immature paramphistomosis is very high and may goup to $80-90 \%$ in domestic ruminants. The rate of paramphistomosis incidence was recorded to be highest (5.42\%) in buffaloes followed by cattle, sheep and goats in Punjab (Hassan et al, 2005). Paramphistomosis is a group of disease caused by the various species of parasites; Paramphistomum epiclitum, P. cervi, Gastrothylax crumenifer, Gigantocotyle explanatum and Fischoederius elongatus are found to be predominant in domestic ruminants. The other amphistome species viz. Cotylophoron bareilliensis and C. indicum found in sheep, C. bareilliensis in goats and $P$. dutti, Duttielacephaloporus, Olveriabosi and O.indica found in buffaloes (Prasadand Varma, 1999). According to Bida \& Schillhorn (1977) sheep which died due to heavy Calicophoron microbothrium infestation showed ulcers and oedema in the intestinal mucosa while cattle experimentally infected with C. microbothrium had catarrhal enteritis and mucosal corrugation (Mavenyengwa et al., 2008). The separasites have complex life cycles and develop through various developmental stages thereby leading to the complexity of the irantigenic moieties. Raising paramphistomeanti bodies experimentally in sheep for the diagnostic purposes and to know the magnitude of the specific disease is quite difficult and a very tedious task. One has to adopt amethodical approach.

\section{MATERIALS AND METHODS}

\section{Maintenance of DonorAnimals}

Animals were kept in the experimental animal shed of the College of Veterinary Sciences providing ad lib food and water as per the guideline of animal ethical committee. Four sheep (age below one year) were initially monitored for any disease through coprological examination. The animals were made free from infection after deworming through Albendazole @ $7.5 \mathrm{mg} / \mathrm{kg}$ body weight to each animal. Sheep were also coprologically examined before giving the infection. Then the animals were utilized for experimental infection with metacercariae of Indoplanor bisexustus for raising paramphistome infected sera.

\section{Collection of snails}

Snails of Indoplanor bisexustus, Gyraulusconv exiusculus and Lymnaea spp. (the intermediate host) was collected mainly nearby tube wells, paddy fields, ditches, impoundments, ponds and from the bank of the river and, its surrounding temporary water bodies (Fig.1). The snails were collected during monsoon and post-monsoon season. During this season snails were found to be heavily positive for paramphistome cercariae. The collected snails are brought up in the laboratory, immediately after removing the debris and proper washing with tap water.

\section{Rearing/maintenance of Snails}

Snails were maintained in the laboratory in earth enwarepot sort ray on artificial diet consisting of Farex (Glaxo) and fresh spinach leaves. Utmost care was takento see that food provided was consumed completely and not much was left to avoid rottening of leaves to keep the water clean. Regularly changed the water of the tray. Large sizes nails were also kept in separate tray (Fig.2). 

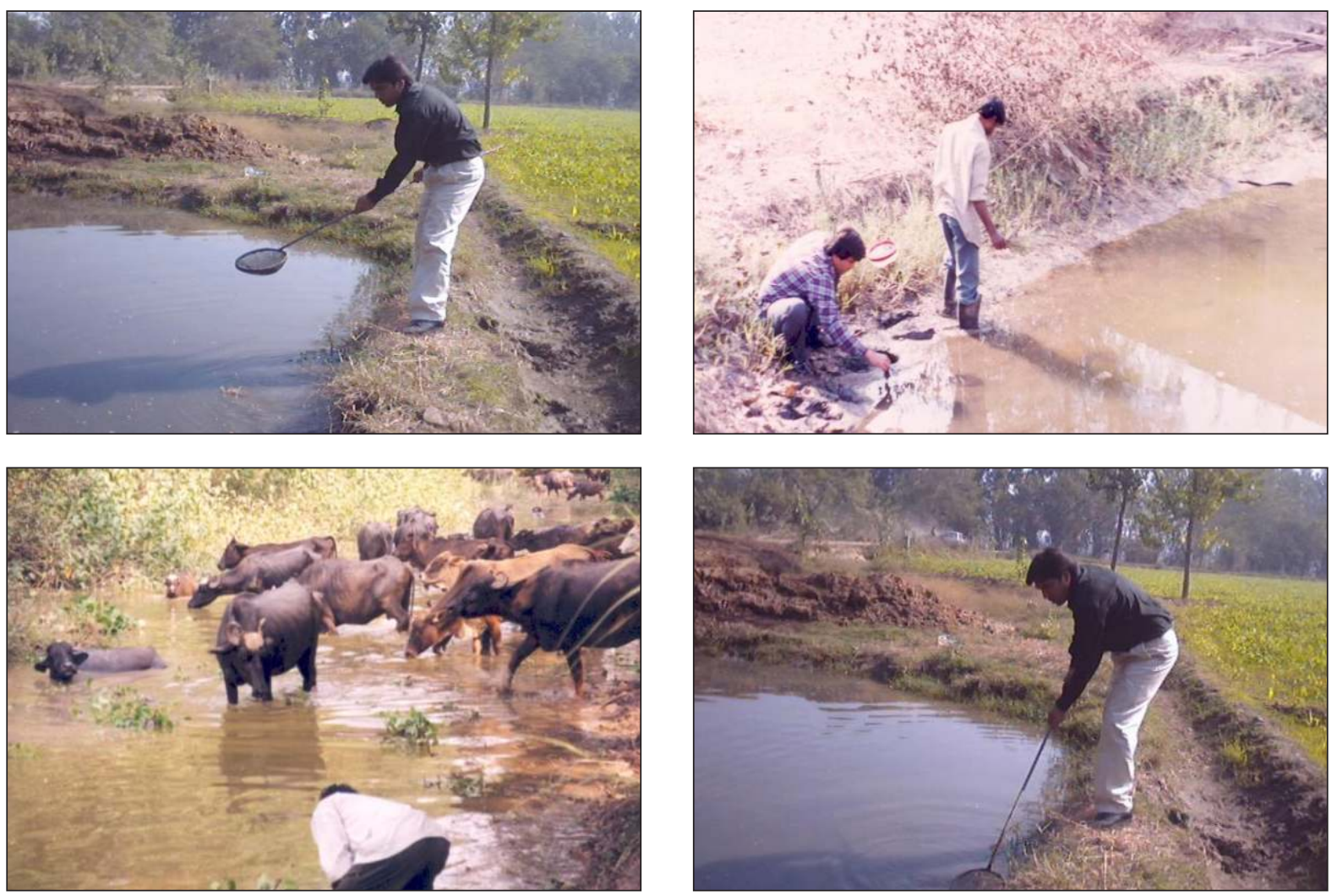

Fig.1: Collection of Snails from ditches, pond, paddy field at Ludhiana.

\section{Screening of Snails}

Collected snails were screened individually for paramphistome infection as per Leiper's glass tube technique. Then snails were exposed to artificial light (40to60 watt can descent bulb) and within an hour cercariae emerged from the infected snails (Fig.2). Simultaneously cercariae were examined and identified under microscope following standard literature. Emerging cercariae was identified using the key of Frandsen \& Chistensen (1984) and the percentage of snails (Indoplanor bisexustus) shedding paramphistome cercariae. Paramphistome infected snails were kept separately for harvesting metacercariae was counted.

\section{Collection of Metacercariae}

The snails were collected and screened individually in glass tube. Positive snails were selected and kept in enamel tray. The paramphistome infected snails were kept separately for harvesting metacercariae. Metacercariae of Paramphistomum epiclitum were harvested on polythene sheets, plastic tray, leaves from positive Indoplanor bisexustus (intermediate host) maintained under laboratory conditions for raising the experimental infection in sheep. These were processed and stored at inpolyvenyltubeat $4{ }^{\circ}$ Cuntilused (Fig.2). The viability of each batch of harvested metacercariae were microscopically tested and counted prior to oral administration of infection dose to the animals as per plan.

\section{Viability Testing of Metacercariae}

Viability of stored metacercariae was tested for maximum establishment offlukes before giving infection to donor animals. The test was studied under twomethods viz., in vitro motility of juveniles and in vitro excystment in artificial media.

\section{Establishment of Experimental Infection in Sheep} Paramphistomemetacercariaeiscollectedforexperime ntalproductionofdiseasesindonoranimalsi.e.sheepafte rexposingthesnailsagainstartificiallight or sunlight. The metacercariae collected from white/coloured (yellow, lightgreen) polythene sheets, leaves and walls of the container after proper counting. The donor animals were starved for 12 hours before giving the 
infection. It was necessary to ensure that metacercariae have to being ested by the animals. Metacercariaein small quantity of water in a glass syringe was poured in to the oral cavity, followed by giving some water and closing of the mouth. Regular monitoring and faecal examination of experimentally infected animal was undertaken to know them agnitude of infection.

\section{Collection of Sera}

The blood samples were collected in sterilized tubes from jugular vein of the donor animals from zero day of infection till $12^{\text {th }}$ week post infection. The samples were marked and kept in slanted position. The sera samples were collected in $1.5 \mathrm{ml}$ aliquot after centrifuging at 3,000 rpm for 15 minutes. One drop of thiomersal $(1: 10,000)$ per $\mathrm{ml}$ of sera were added for preventing the bacterial contamination and fungal growth and stored at $-20^{\circ} \mathrm{C}$ till further use for serodiagnostic tests.

\section{Studies on the Epidemiology of Paramphistomosis (Basedon Coprological Examination)}

Fresh faecal samples were collected at twice in a week. Colour and consistency of faeces were examined for detecting indigestion. The presence of immature flukes was examined through processing of individual samples by repeated straining and washing and examination of clear content of mesh screen under stereomicroscope. The coprological examinations of the samples were done through sedimentation and floatation techniques to find out the eggs in faeces and prepatent period of paramphistome.
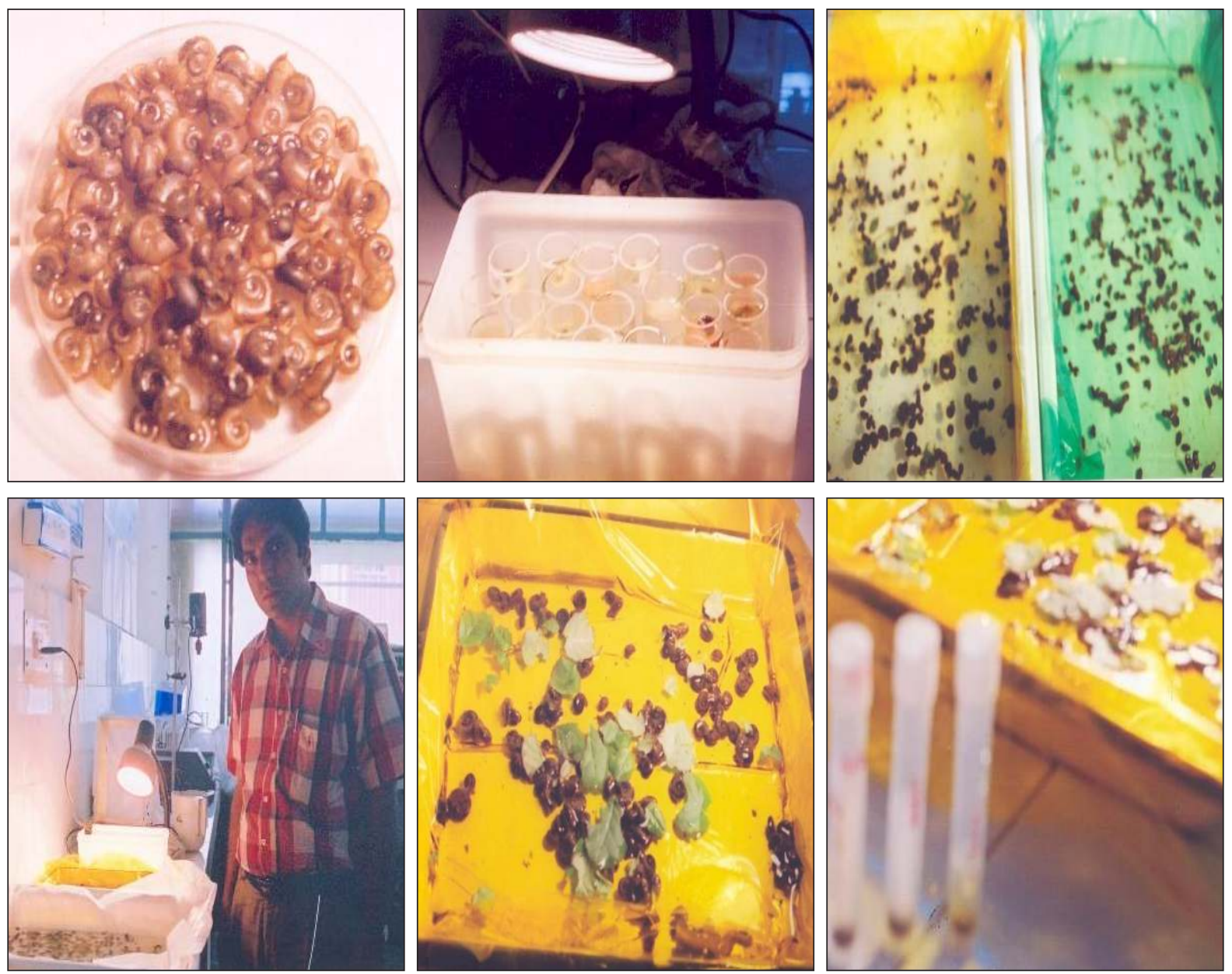

Fig. 2: Map showing harvesting of metacercariae from infected snails (Indoplanor bisexustus) in Laboratory condition. 


\section{RESULTS AND DISCUSSION}

\section{Collection of Snails and Metacercariae (Harvesting and storage)}

Snails of Indoplanor bisexustus, Gyraulusconv exiusculus, Bellamya (Vivipara) bengalensis, Corbicula striatella, Thiaratuberculata, Lymnaealuteola and L. auricularia were collected mainly nearby tube wells, paddy fields, ditches, impoundments, ponds and from the bank of the River Satluj, its surrounding temporary water bodies in Ludhiana, Hoshiarpur, Kapurthala and Amritsar district of Punjab. B. bengalensis, Lymnaeasp, C. striatella, T. tuberculata were found to be the most common species near surrounding areas of the river Satluj and Vyas, however, I. exustus \& G. convexiusculus encountered occasionally from these locations. While the I. exustus, G. convexiusculus and Lymnaeasp were found mainly from the paddyfields, small ditches, nearby tube wells and ponds. The snails (I. exustus and G. convexiusculus) collected during summer (May, June), post-monsoon (September, October) and winter season (November, December) were found positive, as these snails when subjected to light in the laboratory. They started shedding cercariae. However, majority of the snails screened during rest of the month found to be negative where as the snails collected in the month of November, December and June were found heavily positive for paramphistomes and too little extent for schistoso mecercariae. A total of 701 snails were collected, out of which, 365, 4, 165, 127, 16 and 24 were contributed by Indo planor bisexustus, Gyraulus convexiusculus, Lymnaeasp., Viviparabengalensis, Corbicula striatella and Thiara tuberculata respectively. 185 individuals of Indoplanor bisexustus were found to be shedding amphistome cercariae in 60-watt candescent bulb, and $55.89 \%$ snails of $I$. exustus found to be infected. Mousa and Hassan (1972) reported that hatching of the eggs

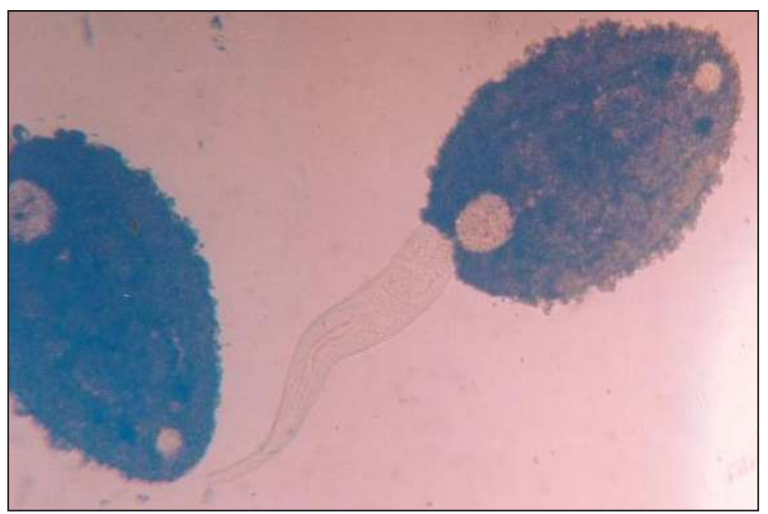

and release of cercariae was directly influenced by temperature. The incubation period became short with the increasing temperature. Similar results have been found in the case of I. exustus in the present work. It is known that seasonal fluctuations affect the growth and survival of snails (Caud, 1958: Mousa and Hassan, 1972). A total of 12,040 metacercariae were collected from 185 infected I. exustus and the metacercariae were given orally to two sheep for raising experimental infection.

The snails, I. exustus were collected from paddy fields, ditches nearby tube well and ponds between the month of September and June. The collected snails brought up in the laboratory, immediately after removing the debris and proper washing with tap water. The snails were kept in different batches individually in glass tubes. Snails in bulk were also kept in beaker, surgical tray, earthen pots and petridishes with white and coloured (green, yellow and pink) polythene sheets. If some snails found dead it was removed from the bulk of the snails. The beaker, surgical tray and petridishes, set in this manner were kept in direct sunlight particularly in the morning hours for one and half hour whereas glass tubes containing I. exustus were exposed against artificial light. Thoroughly checked glass tube after half an hour whether the snails are shedding Cercaria pigmentata (cercariae is a final larval stage, characteristically pigmented, two suckers, forked digestive tract, a pair of eye spots, excretory granules arranged in a characteristic manner, simple tail, cephalic glands and cystogenous glands) or not (Fig.3). Polythene sheets of different colour, white, green, yellow and pink were used for the encystment of cercariae. These sheets were stuck to the inner surface of the petridishes, beakers and surgical tray. Various encystment materials like water plants; lettuce and itsit (Trienthemagovinda) leaves were used.

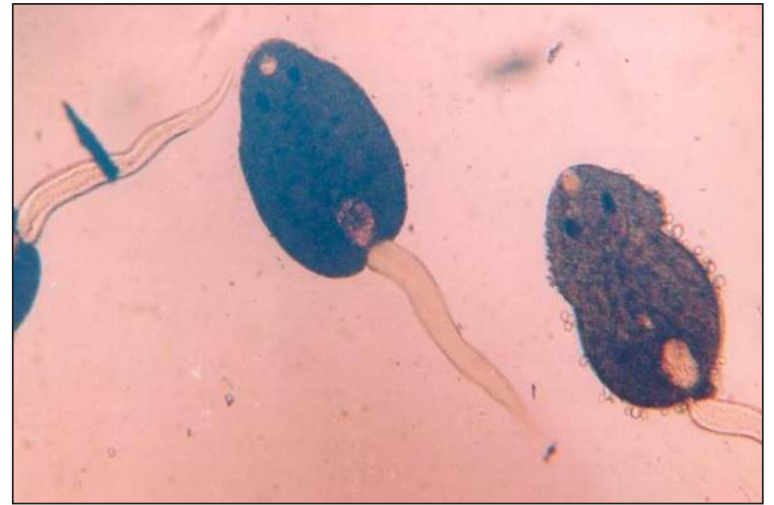

Fig. 3: Cercaria pigmentata. 
It was observedthat maximum attraction of cercariae was towards it sit leaves followed by greenand yellow polythene strips. Very few cercariae were also encysted on the wall of the containers. Durie (1955) used plastic solutions painted on beakers as metacercariae encystment material where as grass blades and mulberry leaves by Jain \& Srivastava (1969) and Chaudhry \& Gupta (1985) respectively. The other encystment material like cellulose casings by Swart \& Reinecke (1962) and waterplants and lettuce leaves by Lengy (1960). A sizeable number of infected snailswere found to be dead due to unfavourable habitat condition. During the present study, a total of 12,040 metacercariae were collected from 185 infected snails (I. exustus) and kept inpolyvenyl tube sand stored at $4^{\circ} \mathrm{C}$. The grass with encysted metacercariae was also collected from the fields for feeding to sheep. Malviya et al (1989) reported paramphistome metacercariae deposited on green polythene strips showed a flukerecovery of $38.66 \%$ in lambs while a lower fluke established was obtained from those deposited on grass blade (11.86\%) and cellulosecasing (8.20\%) respectively. Panzoo et al (1989) reported Gyraulus convexiusculus alone acts as the intermediate host of Gastrothylax crumenifer.

Establishment of Paramphistome Infection in Sheep Experimentally:

Four sheep below one year old were procured from Department of Epidemiology and Preventive Veterinary Medicne and Department of Veterinary Parasitology,Ludhiana. The faecal samples of sheep were subjected to floatation and sedimentation techniques. If found positive for strongyle or any kind of parasitic infection, were given appropriate anthelmintics to make the minfection free. Paramphistome metacercariae $(n=12,040)$ were collected for experimental production of disease in sheep after exposing the snails against artificial light and sunlight. The metacercariae were collected from polythene sheets, leaves and walls of the container after propercounting. Of which, 4000 metacercariae were given to two sheep individually for raising paramphistome infection in experimental condition. The animal was starved for 12 hours before giving the infection. It was necessary to ensure that metacercariae have to being ested by the animals. For this, metacercariae was kept in small quantity of water in a glass tube, then transferred in glass syringe and poured into the oral cavity, followed by givingsome water and closing of the mouth. Regular monitoring and faecal
Snails of all sizes and age groups of Gyraulus convexiusculus were receptive to miracidia and maximum cercariae were shed bythe large size snails exposed to 4 miracidia per snail. The present experiment revealed that large size $I$. exustus were found to be heavily infected and shedding cercariae where as the small one mostly negative. The cercariae were identified ascerearia of Paramphistomum epiclitum (Fig.3). The cercaria play an important role in the life cycle of Paramphistomum species (Fig.4.)

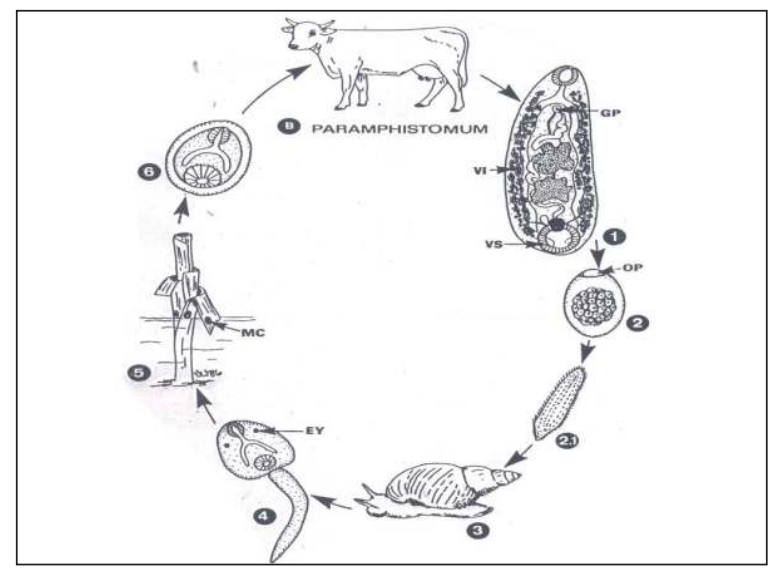

Fig. 4: Life Cycle of Paramphistomum species.

examination through microscope of experimentally infected animal was undertaken to know the magnitude of infection. Faecal samples examined microscopically and found positive for paramphistome eggs after 135 days post infection (Fig.5). The experiments confirm the establishment of paramphistome infection. Serological samples were collected twice in a week for immunodiagnostic tests with various kind of paramphistome antigen for knowing the magnitude of the disease in the sheep and detecting infection at the earliest.

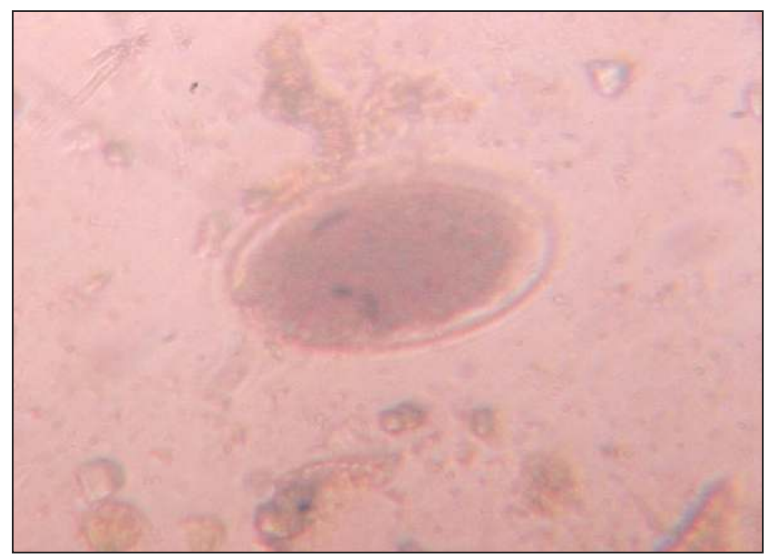




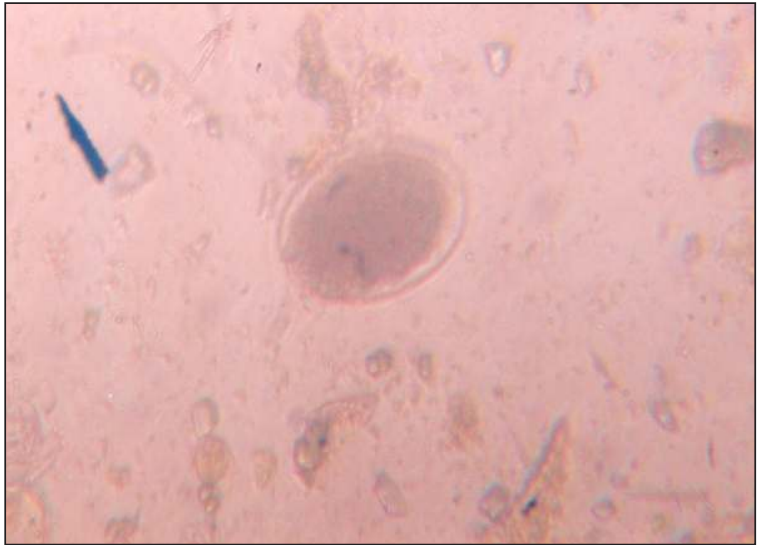

Fig. 5: Eggs of Paramphistomum epiclitum through microscopic examination.

\section{CONCLUSION}

The monitoring of sheep exposed to experimental infection by inoculating metacercariae procured from infected snails (Indoplanor bisexustus) showed the establishment of paramphistomosis. Infection with immature $P$. epiclitum in experimental animal was noticed by observing stress in sheep body including foetiddiarrhoea. Presence of eggs in faecal examination of sheep revealed establishment of experimental infection. Such findings are helpful in exposure of ruminants to paramphistomes and further experiments are planned to study the response to reinfection and determine the duration of the prepatent period. To know the magnitude of the specific disease and raising paramphistome anti bodies experimentally in animal is utmost important for the diagnostic purposes. The establishment of paramphistome infection in domestic ruminants can be achieved with collection and screening of infected snails, proper care, planning, monitoring and examination of experimental animal.

\section{ACKNOWLEDGEMENTS}

Author is thankful to Science \& Engineering Research Council, Department of Science \& Technology, Ministry of Science \& Technology, Govt. of India New Delhi for financial support in the form of DST-SERCFAST-Track project and Guru Angad Dev Veterinary and Animal Sciences University, Ludhiana, for facilities provided.

\section{REFERENCES}

1. Bida S.A., Schillhorn, V.V.T. (1977). Enteric paramphistomiasis in Yankasa sheep. Trop. Anim. Health Prod. 9, 21-23.
2. Caud, J. (1958). Rythmusbiologiques de mollusques Vecteurs des bilbarzioses; Facteurssaisonniers. etc him atiques influencent le cycle de reproduction de Bulinus truncates et de. Planorbariuscn Afrique du Nord. Bull. Wld. Hlth. Org. 18, 751.

3. Chaudhri, S. S. and Gupta, R. P. (1985). Viability and infectivity of Paramphistome metacercariae stored under different condition., Indian Vet. J., 62:470-472.

4. Durie, P.H. (1955). A technique for the collection of large number of paramphistome metacercariae. Aust. J.Agri.Res.,6:202-205.

5. Frandsen, F. and Chistensen, M.O. (1984). An introductory guide to the identification of cercariae from African freshwater snails with special reference to cercariae of trematode species of medical and veterinary importance. Acta Tropica, 41:181-202

6. Hassan, S. S., Kaur, K., Joshi K. and Juyal P. D. (2005). Epidemiology of paramphistomosis in domestic ruminants in different district of Punjab and other adjoining areas, Journal of Veterinary Parasitology, 19(1):43-46.

7. Jain, S. P. and Srivastava, H. D. (1969). The life history of Ceylonocotyles coliocoelium (Fishchoeder, 1904), Nasmark, 1937-Acommon amphistome parasite of ruminants in India. Agra Uni. J. Res.,18:1-16.

8. Lengy, J., (1960). Study on Paramphistomum microbothrium Fishchoeder, 1901, a rumen parasite of attle in Israel. Bulletin Res. Coun. Israel, 9B:71-130.

9. Malviya, H. C., Prasad, A., Varma, T. K., and Dwivedi, P. (1989). On the collection of Paramphistomum cervi metacercariae and their infectivity to lambs, Journal of Veterinary Parasitology., 3(1) 53-55.

10. Mavenyengwa, M., Mukuratirwa, S., Obwolo, M., Monrad, J. (2008). Bovine intestinal cellular responses following primary and challenge infections with Calicophoron microbothrium metacercariae. Onderstepoort J. Vet. Res. 75, 109120.

11. Mousa, A. H. and Hassan, A. A. A. (1972). The effect of water temperature on the snail 
intermediate host of schistosomosis in Egypt. $J$. Egypt. Med. Assn. 55, 148-165.

12. Panzoo G.R, Bali H.S and Singh Sawai (1989). Screening of aquatic snails for the transmission of Gastrothylax crumenifer. Journal of Veterinary Parasitology, 3(1):63-65.

13. Parsad, A. and Varma, T. K. (1999). On the prevalence and community dominance among paramphistomes infecting domestic ruminants. $J$. Vet. Parasitol. 13(2):129-133.
14. Sanabria, R.E.F. and Romero, J.R. (2008). Review and update of paramphistomosis. Helminthologia. 45.2:64 - 68.

15. Swart, P. J. and Reinecke, R. K. (1962). Studies on Paramphistomiasis, 11. The mass production of metacercariae of $P$. microbothrium Fishchoeder, 1901. Onderstepoort J.Vet. Res,29:189-195.

16. Varma, T. K., Prasad, A., Malviya, H.C. and Dwivedi, P. (1989). Incidence of paramphistome infections in ruminants at Bareilly. Indian. J. Anim. Sci., 59(2)231-234. 